\title{
Factors Associated with Neuropsychological Impairment in HIV Infection
}

\author{
Yogita Rai ${ }^{1}$, Tanusree Dutta ${ }^{2}$ and Ambak Kumar Rai ${ }^{3}$ \\ ${ }^{1}$ Department of Psychology, Faculty of Social Sciences, \\ Banaras Hindu University (B.H.U.), Varanasi \\ ${ }^{2}$ Department of Psychology, Mahila Mahavidyalaya, \\ Banaras Hindu University (B.H.U.), Varanasi \\ ${ }^{3}$ Cellular Immunology Division, Department of Transplant \\ Immunology \& Immunogenetics, All India Institute of \\ Medical Sciences (A.I.I.M.S.), Ansari Nagar, New Delhi \\ India
}

\section{Introduction}

In today's world, human immunodeficiency virus (HIV)/acquired immunodeficiency syndrome (AIDS) has poorly affected the vast majority of population and has been declared as one of the worst pandemic. It still remains the major public health burden across the world. The burden of HIV is increasingly progressing and due to lack of adequate knowledge among the population, their management is severely compromised. Advancement in the treatment of these cases are significant. New treatments are capable of reducing plasma viral load and in turn decreasing mortality (Carpenter et al., 1998). The betterment of patients with existing treatment regimen is quite evident, at least clinically and virologically. Here, important question is regarding life threatening impact of virus on various vital functions of the body. That includes central and peripheral nervous system (CNS) function. Such impact of virus becomes more evident, once their number increases to a numeric mark most often at the later stage of infection. However, it is reported that HIV enters the CNS within two weeks of initial infection (Krebs et al., 2000). Neuropsychological compromise are thought to occur secondary to HIV infection (Becker et al., 1997; Bornstein et al., 1993; Grant \& A. Martin, 1994; Heaton et al., 1995; Hinkin et al., 1995; Maj et al., 1994a; Maj et al., 1994b; Martin et al., 1992; Stern, 1991; Van Gorp et al., 1989; von Giesen et al., 2001). When cases are presented, HIV-related neurocognitive disfunctioning may remain unnoticed at very early stage of infection. As the disease progress from asymptomatic to symptomatic and then to full blown AIDS, many neuropsychological impairments of clinical relevance appears in daily life of the patient, which may or may not have any functional significance. Especially, individual infected with HIV who is otherwise physically asymptomatic, these deficits may result in significant morbidity, in the sense that infected people may be unable to perform important tasks (e.g. bathing, cleaning, driving, work tasks), that influence their quality of life (QOL) and healthcare management directly. Such impairments may range from less severe unnoticeable defects to frank dementia syndromes 
that profoundly disrupt an infected individual's functioning and activities of daily living. The neurocognitive deficits typically associated with HIV-1 infection include decrements in motor and information-processing speed, divided attention, memory retrieval processes, and executive functioning. Overall, the gross estimates of people infected HIV who experience neuropsychological impairment is range from $30 \%$ to $50 \%$ of total infected individuals (Grant \& Martin, 1994; Foley et al., 2008).

Neuropsychological impairment can be classified into three subgroups (Grant et at., 1988). First group includes patients with subsyndromic neuropsychological impairment show deficits in at least two neuropsychological domains with no evidence of functional impairment. Second group is mild neurocognitive disorder or minor cognitive/ motor disorder and involve deficits in at least two domains (of ability) of neuropsychological test battery, sufficient affect patient daily functioning. Third group consist of most severe HIV-1 associated dementia which is characterized by moderate to severe cognitive and psychomotor slowing, impaired concentration and attention, memory disturbances and often motor incordination and weakness. Many studies made attempt to found factors associated with neurocognitive impairment in HIV infection. However, factors related to neuropsychological impairment remain poorly understood. Herewith, we have reviewed the possible factors and divided them into three groups depending on their origin. Present chapter is an attempt to review the available literature on the possible factors and to discuss their mechanisms those are associated with neurocognitive impairment (Figure-1).

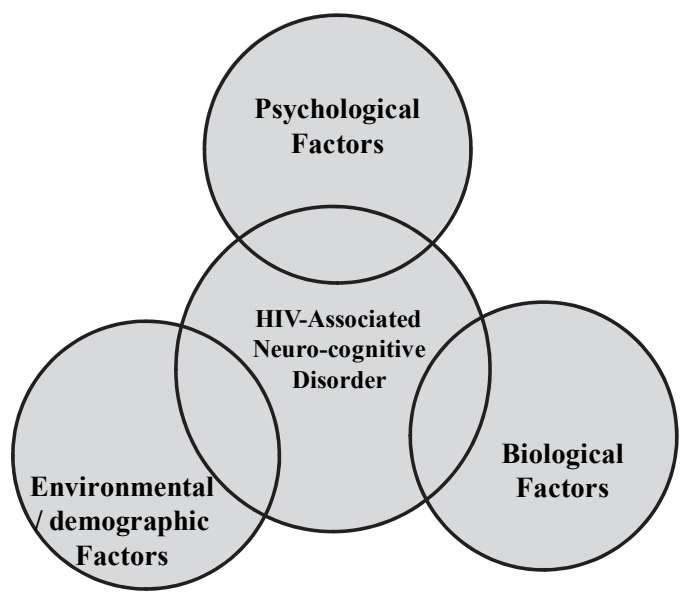

Fig. 1. Factors affecting HIV associated neuro-cognitive impairment

HIV associated neuro-cognitive impairment / disorder are affected by three confounding factors; Biological factors, Psychological factors, Environmental and demographic factors. Initially, HIV does not easily get into the brain. But once it enters through blood-brain barrier and infects the resident microglial cells (a type of macrophage, which harbours the virus). Majority of the influence of biological factors are mediated by direct infection of HIV in brain. Symptoms of HIV associated neuro-cognitive impairments are misjudged with various other psychological problems like depression/ mood disorder, apathy and stress. Environmental and demographic factors like age, gender etc. also influence the HIV mediated neuro-cognitive impairment. 


\section{Biological factors}

\subsection{Direct infection of HIV}

Earlier, for long time, it was never thought of that HIV can also infect brain cells and that led to poor interpretation of many mental disorders associated with HIV-1 infection. Now, this biological stigma has been resolved. HIV-1 targets the cells of lymphoid and myeloid origin containing major HIV-1 receptors, CD4 and various chemokine receptors considered as HIV-1 co-receptors. These receptors help the attachment of the virus to the cell and the fusion of their membrane resulting in the entry of the virus into the cell (Zaitseva et al., 2003). Infected CD4+ T cells and monocytes, which circulate in the blood, are the potential source of CNS infection (Gonzalez-Scarano \& Martin-Garcia, 2005). Many cells, such as T cells and monocytes are infected by HIV-1, these cells circulate in the blood and can cross the blood-brain barrier (BBB) and propagate the infection within the CNS (Figure-2) (Haase, 1986). A major part of HIV-1 associated neurological disfunctioning may be attributed to the entry of HIV-1 into the brain by crossing. The HIV-1 associated neuropathology is characterized by the infiltration of HIV-1 carrying macrophages into the CNS; the formation of microglial nodules; and multinucleated giant cells which result possibly from virusinduced fusion of microglia and/or macrophages in central white and deep gray matter; activation of astrocytes and their damage; neuronal loss particularly in hippocampus, basal ganglia and caudate nucleus. In addition, a variable degree of white matter pathology with evidence of broad range of myelin damage has been reported. HIV-1 has also been detected in the cerebral spinal fluid (CSF) (Gendelman et al., 1994). Imaging of brain using MRI, confirm that HIV infection is associated with progressive cortical atrophy within the gray and white matter, particularly in the later stage of the disease (Hall et al., 1996; Dal Pan et al., 1992; Stout et al., 1998; Aylward et al., 1993). These studies confirm that in the latter stage of infection, the anatomical atrophy in certain parts of brain occurs and many of them proven critical in the daily functioning of the individuals. These studies also report a correlation between the deterioration of cognitive function and the reduction in volume of certain brain structures.

\subsection{Immunodeficiency (opportunistic infections, CD4 \& plasma viral load) 2.2.1 Level of plasma HIV ribonucleic acid (RNA)}

The levels of HIV-1 or its immune-dominant antigens/RNA (viral load) in plasma of infected individuals are the established marker for onset/progress of HIV related pathology. Infection of HIV-1 to brain cells is characterized by their presence in CSF. It is also proven that level of HIV RNA in CSF is elevated in subjects with cognitive impairments (Ellis et al., 1997; McArthur et al., 1997) and it also predicts future neuropsychological impairment (Ellis et al., 2002).The relationship between viral load and the mechanisms of cognitive decline requires further study. Clinically, however, a relationship between plasma HIV RNA levels and cognitive impairment would be more useful for diagnostic point of view. It is postulated that higher plasma HIV RNA levels may be associated with higher levels of circulating HIV-infected monocytes which may enter the blood-brain barrier and affect CNS functioning (Gartner, 2000). However, research on the direct relationship between plasma viral load and cognitive functioning remains equivocal. Various group failed to find a relationship between overall impairment and plasma HIV RNA (Ellis et al. 1997; Reger et al., 2005). However, contradictory reports are also available (Childs et al., 1999; Ellis et al., 2002). In a small neuropsychological battery, Stankoff et al. (1999) found a significant relationship 
between motor functioning and plasma viral load. It seems that plasma viral load is associated with neuropsychological impairment but a lot is required to confirm its role as a predictive marker for neuropsychological impairment. Contradictory reports suggest that a comprehensive, in-depth and longitudinal approach with a multi-domain tool is needed is required to affirm its role as a marker.

\subsubsection{Opportunistic infections}

Opportunistic infections (OIs) of HIV patients significantly reduce their immunity to HIV and this majorly compromised their QOL. OIs generally occur in HIV infected patients with CD4 below 200, when their immune system is not sufficient enough to mount required immunity to prevent the OIs. Development of OIs further compromises their immunity, which in turn aggravates the expansion of HIV-1 and it's spillage into CNS. It is also seen that presence of OIs in HIV infected patients are significantly associated with neuropsychological impairment in HIV infection. The determination of causes of neuropsychological impairment in HIV infection becomes more difficult because of various co-infections associated with it. More often heavy and chronic use of neuro-toxic drugs make it more complicated to study about exact cause. While challenging, these are questions that at one time in the HIV pandemic seemed difficult to imagine.

\subsubsection{Treatment of disease}

The effects of the HAART on neurocognitive functioning have not been assessed, although there have been some scanty studies showing neurocognitive effects of zidovudine (AZT) (Schmitt et al., 1988; Sidtis et al. 1993; Martin et al., 1999). Because drugs (HAART) can cross blood-brain barrier to achieve sufficient concentration to inhibit HIV replication in the CNS (Enting et al, 1998; Tashima, 1998; Limoges et al., 2000). It has also been shown that Zidovudine (AZT) monotherapy at current standard and higher doses can improve neuropsychological performance (Schmitt et al., 1988, Martin et al., 1999) and severity of dementia (Sidtis et al., 1993). However, the benefits of AZT monotherapy may be temporary because of the emergence of viral resistance (Gulevich et al., 1993). It was observed that individuals who are treated with HAART shortly after the first symptoms of dementia appear may show dramatic improvement.

\subsubsection{CD4}

Several studies reported that CD4 count is negatively related with neuropsychological impairment. Bornstein et al., (1991) found that patients with CD4 levels less than 200 had low scores on measures of motor speed, verbal memory acquisition, visual motor speed and mental tracking in comparison to patients with CD4 counts above 200. Osowiecki, et al. (2000) has reported a significant association of CD4 count with neurocognitive deficits. Perry, et al. (1989) found that among HIV positive patients, those scoring in the impaired range on neuropsychological measures had lower CD4 counts and lower CD4 /CD8 ratios than patients scoring in the normal range. It is also suggested that CD4 level correlates significantly with cognitive functioning. Several other studies have reported no relationship between neuropsychological performance and CD4 cell count (McArthur et al., 1989; Saykin et al., 1988; Martin et al., 1998). According to Honni and Bornstein (2002) there is very little evidence to suggest a significant association between CD4 count and the prediction of impairment. 


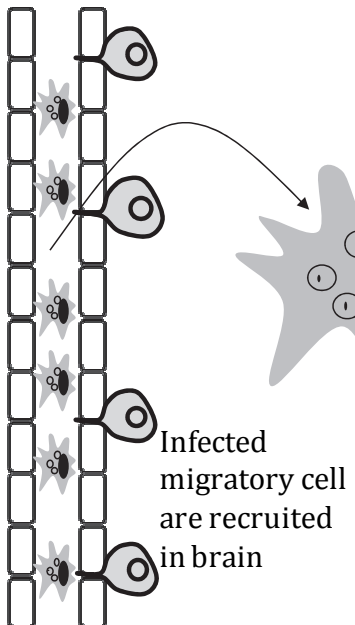

Blood vessel
Brain

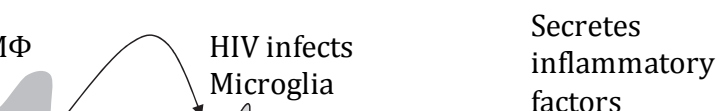

factors

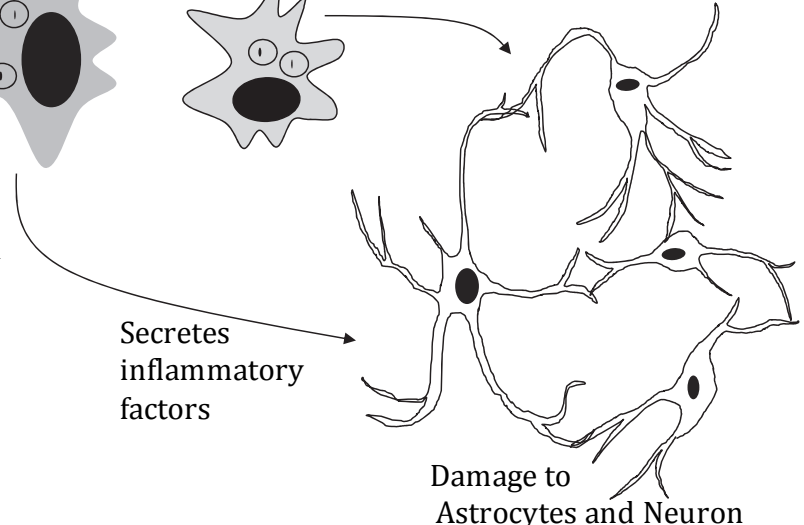

Fig. 2. HIV crosses blood-brain barrier (BBB)

Infected macrophages (carrying HIV) crosses the blood brain barrier and enters into the brain and infects other cells. Infected cells as well as other resident brain cells produce copious amount of mediators (inflammatory factors, various neurotransmitter etc. In the presence of HIV, these factors irreversibly damage the astrocytes and neurons.

\section{Psychological factors}

\subsection{Depression}

Neuropsychological impairments are common in HIV infection with major depression although their nature remains partly unclear. Hypothalamic-pituitary-adrenal axis dysfunction is associated with neuropsychological dysfunction in major depressive disorder although evidence of direct causation is not definitive at present. Appearance of symptoms of depression has been significantly reported in patients with HIV-1 infection (Atkinson, et al., 1988; Perry., 1990; Perkins et al., 1994; Rabkin, 2000). However, the causative co-existence of major depression and neuropsychological impairment has not been reported. Additionally, symptoms of depression and neuropsychological impairment may occur together in many HIV-infected persons. Cysique et al., (2007) reported that neurocognitive impairment and major depression should be considered as two independent processes. Moreover, studies have demonstrated that neuropsychological abnormalities observed in HIV infection are distinct and cannot be attributed to depression (Marsh et al., 1994; Mapou et al., 1993; Perkins et al., 1994; Richardson et al., 1999; Bornstein et al., 1993, Claypoole et al., 1998; Goodwin et al., 1996; Goggin et al., 1997; Grant et al 1988; Moore et al., 1997). It has been shown that depressed patients with HIV-1 infection may exhibit deficits in learning and memory (Claypoole et al., 1998; Goggin et al., 1997; Kalechstein et al. 1998), but the contributions/involvement of depression to the impairment and severity of the 
neuropsychological functioning appear to be minimal. However, more research is needed to confirm and widen these findings, and to expand the knowledge into clinical practice.

\subsection{Apathy}

Apathy refers to a cluster of symptoms reflecting lack of motivation manifested in motoric, emotional, and cognitive domains. To define here, motoric apathy is characterized by the tendency not to initiate a new motor activity unless externally prompted. Emotional apathy is defined as diminished intensity or persistence of emotion, or placidity, relative to the importance of some goal-directed thought or event. The third one, cognitive apathy is defined as indifference, a generalized loss of interest, decrease in goal-directed thought content diminished motivation associated with executive functions, and sometimes decreased verbal fluency. In context to the subject, Castellon et al., (1998) investigated the relationship between apathy, depression, and cognitive performance in HIV infection. They reported that apathy, but not depression, was found to be associated with working memory deficits among HIV subjects. Higher apathy scores and poorer working memory characterized the subjects with AIDS. Castellon et al., (1998) concluded that apathy is independent of depression and may indicate CNS involvement in HIV infection. In contrast, Rabkin et al., (2000) reported that apathy was consistently related to depression and unrelated to neuropsychological impairment.

\subsection{Stress}

Life stress has frequently been examined in the context of psychosocial factors in HIVinfected people because of the known adverse effects of stress on immunity of host (Patterson et al., 1995; Evans et al., 1997). In the context of cognitive function among HIVinfected people, the potential importance of stress has gained increased support from available literature. Moreover, these reports have demonstrated its adverse effects on brain structure and function. Several animal studies have reported atrophy in the CA3 region of the hippocampus in response to stress (Kim \& Yoon, 1998). The chronic stress induced structural changes in brain is mediated by glucocorticoid hormones and neurotransmitters such as serotonin and the GABA-benzodiazepine system (McEwen, 2000) Furthermore, corticosterone a glucocorticoid appears to regulate levels of internal calcium $(\mathrm{Ca} 2+)$ and thus may influence synaptic plasticity, aging, and cell death (Kim \& Yoon, 1998). In context to patients, It has been demonstrated that atrophy in brain and abnormalities in its function are result of heightened levels of glucocorticoids and severe, traumatic stress (McEwen, 2000). In another study, it is observed that stressful life events were significantly related to cognitive performance only in the HIV-infected subjects (Pukay-Martin et al., 2003).

\subsection{Drug addiction}

It is well known that the intravenous administration of drugs with shared needles is an important cause for the spread of HIV burden. The persistent use of drugs through other routes (e.g., inhaling crack/cocaine) may also increase the risk for HIV infection. Drug abusers also practice prostitution to support their livelihood, habit and they may also engage in risky sexual behavior while under the influence of drugs or alcohol. But injection drug use with shared needle has also been seen as a main reason for the rapid progression of HIV among drug abusers (Bouwman et al., 1998), and has been found to diminish overall neuropsychological performance and reduce visuomotor processing, executive functioning, 
motor speed and strength, and sensorimotor perception in persons in the very early stages of HIV infection (Claypoole et al., 1993). It was initially thought that frequent drug usage may impair the cognitive functioning among HIV-seropositive persons for (Wellman, 1992). It was also postulated that drug usage possibly induces CNS impairment independent of that caused by HIV infection. However, this argument does not appear to hold true, asmost studies have found that neuropsychological dysfunction may not be contributed solely or partially by substance abuse, if we do not consider HIV seropositivity (Janssen et al., 1989). It was also suggested that the interaction of HIV infection and drug use might produce additive and synergistic cognitive deficits. Studies suggest that co-presence of HIV infection and drug use does not affect the cognitive functioning (Selnes et al., 1990; Selnes et al., 1992; Goodwin et al., 1996; Bornstein et al., 1993; Bono et al., 1996; Selnes et al., 1995). Cristiani et al., (2004) reported that the effect of marijuana use was greatest in subjects with symptomatic HIV infection. Further inspection suggested that this effect was due primarily to performance on memory tasks. Their finding suggest that although there is minimal impact of marijuana on uninfected individuals or those at early stages of HIV infection, there is a synergistic effect of HIV and marijuana use in patients with advanced HIV disease. Exception to the earlier studies, it was reported that HIV infection and methamphetamine dependence are each associated with neuropsychological deficits, and suggest that these factors in combination are associated with additive deleterious cognitive effects (Rippeth et al., 2004). It is also suggestive of that both HIV infection and methamphetamine dependence can be associated with brain dysfunction.

\section{Environmental and demographic factor}

\subsection{Education}

A certain level of education is required for the prevention and cure of HIV infection. It is now established that low education level is an independent risk factor for HIV-1 related cognitive impairment. Stern et al., (1996), Maj et al., (1994), Satz et al., (1993) reported that low educational level (6 years) increases the risk of HIV-1-related cognitive impairment in HIV-1-seropositive persons (asymptomatic and symptomatic). Our own unpublished data is in concordance with their findings. It is important to note that the association between low educational level and HIV-1-related cognitive impairment was independent of all other putative risk factors. In addition to this, another study also suggests that discrepancy in reading and education level is associated with worse neuropsychological performance (Ryan et al., 2005). There are two possible variables related to literacy, those are frequently used to predict the neuropsychological functioning; reading ability and years of education. In a country like India and particularly in its remote rural areas, it is difficult to predict the total year(s) of education. In such situations, it is better to rely on the reading ability of an individual. In other parts of world, previous research has also shown that reading ability is a stronger predictor of cognitive functioning than year(s) of education. Dotson et al., (2009) reported that reading ability predicts cognitive functioning than year(s) of education. They also suggest that influence of literacy and year(s) of education on cognitive functioning may vary among individuals belong to certain racial minority status and low SES group.

\subsection{Age}

The impact of age on some aspects of neuropsychological performance is well established. In addition, data indicate that age at the time of seroconversion is significantly associated 
with HIV disease progression and survival time (Babiker et al., 2001). The possibility of an interaction between age and disease level on cognitive function has not been explored thoroughly. Both age and HIV status have been established as independent risk factors for the development of cognitive impairment, it is both reasonable and important to question whether the interaction of these two factors may constitute increased risk of impairment in HIV-infected individuals. While several studies have explored the impact of age on cognitive function in HIV infected subjects (Janssen et al., 1992; McArthur et al., 1993; Kim et al., 2001; Pereda et al., 2000) few have examined the interaction of age and disease status (Van Gorp et al., 1994; Hardy et al., 1999). Kissel et al., (2005) reported that Age and disease status had independent effects on cognitive function, but there were no significant interactions either on a summary measure of performance or on individual test scores.

\subsection{Gender}

Chiesi et al. and the AIDS in Europe Study Group (1996) reported that rates of cognitive impairment were higher for women. The hypothesis that female seropositive subjects are more vulnerable for neuropsychological impairment than seropositive men, is explained by Satz et al. (1993) that they usually have an extensive pre-morbid history, a history of substance abuse, a lower economic level, a greater psychiatric morbidity and a low educational level (Ickovics \& Rodin, 1992; Melnick et al., 1994) variables that could increase the risk of neuropsychological impairment associated with HIV-1 (Stern et al., 1996). FaíldeGarrido et al. (2008) reported different neuropsychological impairment pattern was detected between genders: while HIV+ men had greater impairment in visual memory, attention, psychomotor speed and abstract reasoning, HIV+ women had greater impairment on attention, psychomotor speed and verbal memory for texts. They further reported that there is no difference between the neuropsychological performance of seropositive male and female subjects. Pereda et al. (2000), Rabkin et al. (2000) found same result.

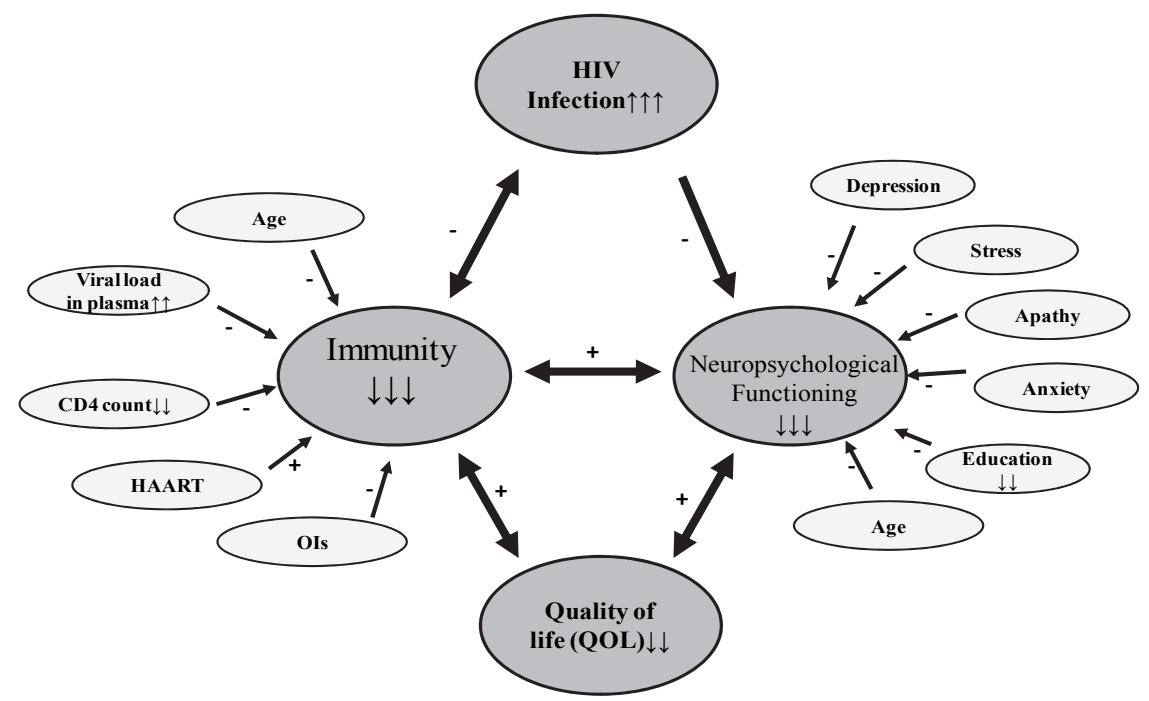

Fig. 3. Figure showing interrelationship among HIV infection, immunity of the host, neuropsychological functioning and quality of life (QOL) 
HIV infection, immunity of the host, neuropsychological functioning and QOL are interlinked and affects each other. Various factors may influence neuropsychological functioning and immunity of the host. (-) and (+) sign shows negative association respectively. $\rightarrow$ and $\leftrightarrow$ depicts uni and bidirectional interaction between two.

\section{Conclusion}

In conclusion, much can learn about factors associated with neuropsychological impairment, a leading cause of morbidity and mortality in persons with HIV infection. It was the intent of this manuscript not only to summarize what we know about factors associated with neuropsychological impairment in HIV infection but also to point out what we don't know and to highlight future directions that this area of research must now address. The adverse effect of HIV on neuropsychological functioning is well established. Manifestations of neurocognitive dysfunction range from subtle and mild cognitive changes to frank dementia syndromes. We have primarily focused on the factors associated with neuropsychological impairment, which is adversely affect QOL and patients' ability demanding daily activities (Figure-3). There are very few studies focusing on factors associated with neuropsychological impairment in HIV infection. This review categorized factors into three broad areas that significantly associated with neuropsychological impairment. There are lacks of consensus among available literature regarding factors associated with neuropsychological impairment in HIV infection, especially psychological and environmental/demographic factors. Contradictory finding have been reported regarding association between neuropsychological impairment and antiretroviral therapy, drug abuse, depression, apathy, stress, age, gender and education. This review help the health care professionals in proper care of HIV seropositive people those are at risk to develop cognitive impairment. Present chapter also mentions the fact that tertiary prevention is urgently needed to improve quality of life of HIV infected people. Comprehensive study is needed to explore the above relationship and is clearly an important area of investigations.

\section{Acknowledgement}

The authors thank all the patients and control subjects who volunteered participation in their study. We also thank Indian Council of Social Science and Research (ICSSR), Government of India for providing fellowship to Dr. Yogita Rai. The authors also thank Prof. A. K. Gulati, Department of Microbiology, Institute of Medical Sciences, Banaras Hindu University.

\section{References}

Atkinson, J.H., Jr, Grant, I, Kennedy, C. J., Richman, D. D., Spector, S A, \& McCutchan, J A. (1988). Prevalence of psychiatric disorders among men infected with human immunodeficiency virus. A controlled study. Archives of General Psychiatry, Vol. 45, No. 9, (Sep 1988), pp. (859-864), ISSN 0003-990X

Aylward, E. H., Henderer, J. D., McArthur, J. C., Brettschneider, P. D., Harris, G. J., Barta, P. E., \& Pearlson, G. D. (1993a). Reduced basal ganglia volume in HIV-1-associated dementia: results from quantitative neuroimaging. Neurology, Vol. 43, No. 10, (Oct 1993), pp. (2099-2104), ISSN 0028-3878 
Babiker, A. G., Peto, T., Porter, K., Walker, A. S., \& Darbyshire, J. H. (2001). Age as a determinant of survival in HIV infection. Journal of Clinical Epidemiology, Vol. 54, No. 1, (Dec 2001), pp. (S16-21), ISSN 0895-4356

Becker, J. T., Sanchez, J., Dew, M. A., Lopez, O. L., Dorst, S. K., \& Banks, G. (1997b). Neuropsychological abnormalities among HIV-infected individuals in a community-based sample. Neuropsychology, Vol. 11, No. 4, (Mar 25, 2011), pp. (592601), ISSN 1573-3254

Bono, G., Mauri, M., Sinforiani, E., Barbarini, G., Minoli, L., \& Fea, M. (1996). Longitudinal neuropsychological evaluation of HIV-infected intravenous drug users. Addiction (Abingdon, England), Vol. 91, No. 2, (Feb 1996), pp. (263-268), ISSN 0965-2140

Bornstein, R A, Nasrallah, H. A., Para, M. F., Fass, R. J., Whitacre, C. C., \& Rice, R. R., Jr. (1991). Rate of CD4 decline and neuropsychological performance in HIV infection. Archives of Neurology, Vol. 48, No. 7, (Jul 1991), pp. (704-707), ISSN 0003-9942

Bornstein, R A, Nasrallah, H. A., Para, M. F., Whitacre, C. C., \& Fass, R. J. (1993). Change in neuropsychological performance in asymptomatic HIV infection: 1-year follow-up. AIDS (London, England), Vol. 7, No. 12, (Dec 1993), pp. (1607-1611), ISSN 0269-9370

Bornstein, R A, Pace, P., Rosenberger, P., Nasrallah, H. A., Para, M. F., Whitacre, C. C., \& Fass, R. J. (1993d). Depression and neuropsychological performance in asymptomatic HIV infection. The American Journal of Psychiatry, Vol. 150, No. 6, (Jun 1993), pp. (922-927), ISSN 0002-953X

Bouwman, F. H., Skolasky, R. L., Hes, D., Selnes, O. A., Glass, J. D., Nance-Sproson, T. E., Royal, W., et al. (1998c). Variable progression of HIV-associated dementia. Neurology,Vol. 50 ,No.6,( Jun 1998), PP.(1814-1820) ISSN 0028-3878

Carpenter, C. C., Fischl, M. A., Hammer, S. M., Hirsch, M. S., Jacobsen, D. M., Katzenstein, D. A., Montaner, J. S., et al. (1998). Antiretroviral therapy for HIV infection in 1998: updated recommendations of the International AIDS Society-USA Panel. JAMA: The Journal of the American Medical Association, Vol. 280, No. 1,( Jul 1, 1998), pp. (7886) ISSN 0098-7484

Castellon, S. A., Hinkin, C H, Wood, S., \& Yarema, K. T. (1998). Apathy, depression, and cognitive performance in HIV-1 infection. The Journal of Neuropsychiatry and Clinical Neurosciences, Vol. 10, No.3, PP. (320-329) ISSN 0895-0172

Chiesi, A., Vella, S., Dally, L. G., Pedersen, C., Danner, S., Johnson, A. M., Schwander, S., et al. (1996). Epidemiology of AIDS dementia complex in Europe. AIDS in Europe Study Group. Journal of Acquired Immune Deficiency Syndromes and Human Retrovirology: Official Publication of the International Retrovirology Association, Vol. 11, No. 1, (Jan 1996), pp. (39-44), ISSN 1077-9450

Childs, E. A., Lyles, R. H., Selnes, O. A., Chen, B., Miller, E. N., Cohen, B. A., Becker, J. T., et al. (1999d). Plasma viral load and CD4 lymphocytes predict HIV-associated dementia and sensory neuropathy. Neurology, Vol. 52, No. 3, (Feb 1999), pp. (607613), ISSN 0028-3878

Claypoole, K. H., Elliott, A. J., Uldall, K. K., Russo, J., Dugbartey, A. T., Bergam, K., \& RoyByrne, P. P. (1998). Cognitive functions and complaints in HIV-1 individuals treated for depression. Applied Neuropsychology, Vol. 5, No. 2, (), pp. (74-84), ISSN 0908-4282

Claypoole, K. H., Townes, B. D., Collier, A. C., Marra, C., Longstreth, W. T., Jr, Cohen, W., Martin, D., et al. (1993). Cognitive risk factors and neuropsychological performance in HIV infection. The International Journal of Neuroscience, Vol. 70, No. 1-2, (May 1993), pp. (13-27), ISSN 0020-7454 
Cristiani, S. A., Pukay-Martin, N. D., \& Bornstein, Robert A. (2004). Marijuana use and cognitive function in HIV-infected people. The Journal of Neuropsychiatry and Clinical Neurosciences, Vol. 16, No. 3, pp. (330-335), 0895-0172

Cysique, L. A., Deutsch, R., Atkinson, J Hampton, Young, C., Marcotte, Thomas D, Dawson, L., Grant, Igor, et al. (2007). Incident major depression does not affect neuropsychological functioning in HIV-infected men. Journal of the International Neuropsychological Society: JINS, Vol. 13, No. 1, (Jan 2007), pp. (1-11), ISSN 1355-6177

Dal Pan, G. J., McArthur, J. H., Aylward, E., Selnes, O. A., Nance-Sproson, T. E., Kumar, A. J., Mellits, E. D., et al. (1992e). Patterns of cerebral atrophy in HIV-1-infected individuals: results of a quantitative MRI analysis. Neurology, Vol. 42, No. 11, (Nov 1992), pp. (2125-2130), ISSN 0028-3878

Dotson, V. M., Kitner-Triolo, M. H., Evans, M. K., \& Zonderman, A. B. (2009). Effects of race and socioeconomic status on the relative influence of education and literacy on cognitive functioning. Journal of the International Neuropsychological Society: JINS, Vol. 15, No. 4, (Jul 2009), pp. (580-589), ISSN 1469-7661

Ellis, R J, Hsia, K, Spector, S A, Nelson, J. A., Heaton, R K, Wallace, M. R., Abramson, I., et al. (1997). Cerebrospinal fluid human immunodeficiency virus type 1 RNA levels are elevated in neurocognitively impaired individuals with acquired immunodeficiency syndrome. HIV Neurobehavioral Research Center Group. Annals of Neurology, Vol. 42, No. 5, (Nov 1997), pp. (679-688), ISSN 0364-5134

Ellis, Ronald J, Moore, D. J., Childers, M. E., Letendre, S., McCutchan, J Allen, Wolfson, Tanya, Spector, Stephen A, et al. (2002). Progression to neuropsychological impairment in human immunodeficiency virus infection predicted by elevated cerebrospinal fluid levels of human immunodeficiency virus RNA. Archives of Neurology, Vol. 59, No. 6, (Jun 2002), pp. (923-928), ISSN 0003-9942

Enting, R. H., Hoetelmans, R. M., Lange, J. M., Burger, D. M., Beijnen, J. H., \& Portegies, P. (1998). Antiretroviral drugs and the central nervous system. AIDS (London, England), Vol. 12, No. 15, (Oct 1998), pp. (1941-1955), ISSN 0269-9370

Evans, D. L., Leserman, J., Perkins, D. O., Stern, R. A., Murphy, C., Zheng, B., Gettes, D., et al. (1997a). Severe life stress as a predictor of early disease progression in HIV infection. The American Journal of Psychiatry, Vol. 154, No. 5, (May 1997), pp. (630634), ISSN 0002-953X

Faílde-Garrido, J. M., Alvarez, M. R., \& Simón-López, M. A. (2008). Neuropsychological impairment and gender differences in HIV-1 infection. Psychiatry and Clinical Neurosciences, Vol. 62, No. 5, (Oct 2008), pp. (494-502), ISSN 1440-1819

Foley, J., Ettenhofer, M., Wright, M., \& Hinkin, Charles H. (2008). Emerging issues in the neuropsychology of HIV infection. Current HIV/AIDS Reports, Vol. 5, No. 4, (Nov 2008), pp. (204-211), ISSN 1548-3576

Gartner, S. (2000). HIV infection and dementia. Science (New York, N.Y.), Vol. 287, No. (5453), (Jan 2000), pp. 602-604, ISSN 0036-8075

Gendelman, H. E., Lipton, S. A., Tardieu, M., Bukrinsky, M. I., \& Nottet, H. S. (1994). The neuropathogenesis of HIV-1 infection. Journal of Leukocyte Biology, Vol. 56, No. 3, (Sep 1994), pp. (389-398), ISSN 0741-5400

von Giesen, H. J., Bäcker, R., Hefter, H., \& Arendt, G. (2001). Depression does not influence basal ganglia-mediated psychomotor speed in HIV-1 infection. The Journal of Neuropsychiatry and Clinical Neurosciences, Vol. 13, No. 1, pp. (88-94), ISSN 0895-0172

Goggin, K. J., Zisook, S., Heaton, R K, Atkinson, J H, Marshall, S., McCutchan, J A, Chandler, J. L., et al. (1997). Neuropsychological performance of HIV-1 infected men with 
major depression. HNRC Group. HIV Neurobehavioral Research Center. Journal of the International Neuropsychological Society: JINS, Vol. 3, No. 5, (Sep 1997), pp. (457464), ISSN 1355-6177

González-Scarano, F., \& Martín-García, J. (2005). The neuropathogenesis of AIDS. Nature Reviews. Immunology, Vol. 5, No. 1, (Jan 2005), pp. (69-81), ISSN 1474-1733

Goodwin, G. M., Pretsell, D. O., Chiswick, A., Egan, V., \& Brettle, R. P. (1996a). The Edinburgh cohort of HIV-positive injecting drug users at 10 years after infection: a case-control study of the evolution of dementia. AIDS (London, England), Vol. 10, No. 4, (Apr 1996), pp. (431-440), ISSN 0269-9370

Grant, I, Atkinson, J H, Hesselink, J. R., Kennedy, C. J., Richman, D. D., Spector, S A, \& McCutchan, J A. (1988a). Human immunodeficiency virus-associated neurobehavioural disorder. Journal of the Royal College of Physicians of London, Vol. 22, No. 3, (Jul 1988), pp. (149-157), ISSN 0035-8819

Grant, I, \& Martin, A. (1994). Neuropsychology of HIV Infection. New York: Osford Univ Press.

Gulevich, S. J., McCutchan, J A, Thal, L. J., Kirson, D., Durand, D., Wallace, M., Mehta, P., et al. (1993). Effect of antiretroviral therapy on the cerebrospinal fluid of patients seropositive for the human immunodeficiency virus. Journal of Acquired Immune Deficiency Syndromes, Vol. 6, No. 9, (Sep 1993), pp. (1002-1007), ISSN 0894-9255

Haase, A. T. (1986). Pathogenesis of lentivirus infections. Nature, Vol. 322, No. 6075, (Jul 1986), pp. (130-136), ISSN 0028-0836

Hall, M., Whaley, R., Robertson, K., Hamby, S., Wilkins, J., \& Hall, C. (1996). The correlation between neuropsychological and neuroanatomic changes over time in asymptomatic and symptomatic HIV-1-infected individuals. Neurology, Vol. 46, No. 6, (Jun 1996), pp. (1697-1702), ISSN 0028-3878

Hardy, D. J., Satz, P., \& Jones, F. D. (1999). Age differences and neurocognitive performance in HIV-infected adults. New Zealand Journal of Psychology, Vol. 28, pp. (94-101), ISSN 0112-109X

Heaton, R K, Grant, I, Butters, N., White, D. A., Kirson, D., Atkinson, J H, McCutchan, J A, et al. (1995). The HNRC 500--neuropsychology of HIV infection at different disease stages. HIV Neurobehavioral Research Center. Journal of the International Neuropsychological Society: JINS, Vol. 1, No. 3, (May 1995), pp. (231-251), ISSN 13556177

Hinkin, C H, van Gorp, W. G., Mandelkern, M. A., Gee, M., Satz, P., Holston, S., Marcotte, T D, et al. (1995). Cerebral metabolic change in patients with AIDS: report of a sixmonth follow-up using positron-emission tomography. The Journal of Neuropsychiatry and Clinical Neurosciences, Vol. 7, No. 2, pp. (180-187), ISSN 08950172

Honn, V. J., Bornstein (2002). Social support, neuropsychological performance, and depression in HIV infection. Journal of the International Neuropsychological Society: JINS, Vol. 8, No. 3, (Mar 2002), pp. (436-447), ISSN 1355-6177

Ickovics, J. R., \& Rodin, J. (1992). Women and AIDS in the United States: epidemiology, natural history, and mediating mechanisms. Health Psychology: Official Journal of the Division of Health Psychology, American Psychological Association, Vol. 11, No. 1, pp. (1-16), ISSN 0278-6133

Janssen, R. S., Nwanyanwu, O. C., Selik, R. M., \& Stehr-Green, J. K. (1992). Epidemiology of human immunodeficiency virus encephalopathy in the United States. Neurology, Vol. 42, No. 8, (Aug 1992), pp. (1472-1476) ISSN 0028-3878. 
Janssen, R. S., Saykin, A. J., Cannon, L., Campbell, J., Pinsky, P. F., Hessol, N. A., O'Malley, P. M., et al. (1989). Neurological and neuropsychological manifestations of HIV-1 infection: association with AIDS-related complex but not asymptomatic HIV-1 infection. Annals of Neurology, Vol. 26, No. 5, (Jan 1989), pp. (592-600), ISSN 00283878

Kalechstein, A. D., Hinkin, C H, van Gorp, W. G., Castellon, S. A., \& Satz, P. (1998f). Depression predicts procedural but not episodic memory in HIV-1 infection. Journal of Clinical and Experimental Neuropsychology, Vol. 20, No. 4, (Aug 1998), pp. (529535), ISSN 1380-3395.

Kim, D. H., Jewison, D. L., Milner, G. R., Rourke, S. B., Gill, M. J., \& Power, C. (2001). Neurocognitive symptoms and impairment in an HIV community clinic. The Canadian Journal of Neurological Sciences. Le Journal Canadien Des Sciences Neurologiques, Vol. 28, No. 3, (Aug 2001), pp. (228-231), ISSN 0317-1671.

Kim, J. J., \& Yoon, K. S. (1998). Stress: metaplastic effects in the hippocampus. Trends in Neurosciences, Vol. 21, No. 12, (Dec 1998), pp. (505-509), ISSN 0166-2236.

Kissel, E. C., Pukay-Martin, N. D., \& Bornstein, Robert A. (2005). The relationship between age and cognitive function in HIV-infected men. The Journal of Neuropsychiatry and Clinical Neurosciences, Vol. 17 No.2, pp. (180-184) ISSN 0895-0172

Krebs, F. C., Ross, H., McAllister, J., \& Wigdahl, B. (2000). HIV-1-associated central nervous system dysfunction. Advances in Pharmacology (San Diego, Calif.), Vol. 49, pp. (315385), ISSN 1054-3589

Limoges, J., Persidsky, Y., Poluektova, L., Rasmussen, J., Ratanasuwan, W., Zelivyanskaya, M., McClernon, D. R., et al. (2000). Evaluation of antiretroviral drug efficacy for HIV-1 encephalitis in SCID mice. Neurology, Vol. 54, No. 2, ( Jan 25, 2000) ,pp. (379389), ISSN 0028-3878

Maj, M., Janssen, R., Starace, F., Zaudig, M., Satz, P., Sughondhabirom, B., Luabeya, M. A., et al. (1994). WHO Neuropsychiatric AIDS study, cross-sectional phase I. Study design and psychiatric findings. Archives of General Psychiatry, Vol. 51, No. 1, (Jan 1994), pp. (39-49), ISSN 0003-990X

Maj, M., Satz, P., Janssen, R., Zaudig, M., Starace, F., D’Elia, L., Sughondhabirom, B., et al. (1994). WHO Neuropsychiatric AIDS study, cross-sectional phase II. Neuropsychological and neurological findings. Archives of General Psychiatry, Vol. 51, No. 1, (Jan 1994), pp. (51-61), ISSN 0003-990X

Mapou, R. L., Law, W. A., Martin, A., Kampen, D., Salazar, A. M., \& Rundell, J. R. (1993). Neuropsychological performance, mood, and complaints of cognitive and motor difficulties in individuals infected with the human immunodeficiency virus. The Journal of Neuropsychiatry and Clinical Neurosciences, Vol. 5, No.1, pp. (86-93) ISSN 0895-0172

Marsh, N. V., \& McCall, D. W. (1994). Early neuropsychological change in HIV infection. Neuropsychology, Vol. 8, No. 1, (Jan 1994 ), pp. (44-48)

Martin, A., Heyes, M. P., Salazar, A. M., Kampen, D. L., Williams, J., Law, W. A., Coats, M. E., et al. (1992). Progressive slowing of reaction time and increasing cerebrospinal fluid concentrations of quinolinic acid in HIV-infected individuals. The Journal of Neuropsychiatry and Clinical Neurosciences, Vol. 4, No. 3, pp. (270-279), ISSN 08950172

Martin, E. M., Pitrak, D. L., Novak, R. M., Pursell, K. J., \& Mullane, K. M. (1999). Reaction times are faster in HIV-seropositive patients on antiretroviral therapy: A 
preliminary report. Journal of Clinical and Experimental Neuropsychology, Vol. 21, No. 5, (Oct 1999) pp. (730-735) ISSN 1380-3395

Martin, E. M., Robertson, L. C., Edelstein, H. E., Jagust, W. J., Sorensen, D. J., San Giovanni, D., \& Chirurgi, V. A. (1992). Performance of patients with early HIV-1 infection on the Stroop Task. Journal of Clinical and Experimental Neuropsychology, Vol. 14, No. 5, (Sep 1992), pp. (857-868) ISSN 1380-3395

McArthur, J. C., Becker, P. S., Parisi, J. E., Trapp, B., Selnes, O. A., Cornblath, D. R., Balakrishnan, J., et al. (1989g). Neuropathological changes in early HIV-1 dementia. Annals of Neurology, Vol. 26, No. 5, (Nov 1989), pp. (681-684), ISSN 0364-5134

McArthur, J. C., Hoover, D. R., Bacellar, H., Miller, E. N., Cohen, B. A., Becker, J. T., Graham, N. M., et al. (1993). Dementia in AIDS patients: incidence and risk factors. Multicenter AIDS Cohort Study. Neurology, Vol. 43, No. 11, (Nov 1993), pp.( 22452252), ISSN 0028-3878

McArthur, J. C., McClernon, D. R., Cronin, M. F., Nance-Sproson, T. E., Saah, A. J., St Clair, M., \& Lanier, E. R. (1997h). Relationship between human immunodeficiency virusassociated dementia and viral load in cerebrospinal fluid and brain. Annals of Neurology, Vol. 42, No. 5, (Nov 1997), pp. (689-698), ISSN 0364-5134

McEwen, B. S. (2000). The neurobiology of stress: from serendipity to clinical relevance. Brain Research, Vol. 886, No. 1-2, (Dec 15, 2000), pp.(172-189), ISSN 0006-8993

Melnick, S. L., Sherer, R., Louis, T. A., Hillman, D., Rodriguez, E. M., Lackman, C., Capps, L., et al. (1994). Survival and disease progression according to gender of patients with HIV infection. The Terry Beirn Community Programs for Clinical Research on AIDS. JAMA: The Journal of the American Medical Association, Vol. 272, No. 24, (Dec 28, 1994), pp. (1915-1921), ISSN 0098-7484

Moore, L. H., van Gorp, W. G., Hinkin, C H, Stern, M. J., Swales, T., \& Satz, P. (1997i). Subjective complaints versus actual cognitive deficits in predominantly symptomatic HIV-1 seropositive individuals. The Journal of Neuropsychiatry and Clinical Neurosciences, Vol. 9, No. 1, pp. (37-44), ISSN 0895-0172

Osowiecki, D. M., Cohen, R. A., Morrow, K. M., Paul, R. H., Carpenter, C. C., Flanigan, T., \& Boland, R. J. (2000). Neurocognitive and psychological contributions to quality of life in HIV-1-infected women. AIDS (London, England), Vol. 14, No. 10, (Jul 2000), pp. (1327-1332), ISSN 0269-9370

Patterson, T. L., Semple, S. J., Temoshok, L. R., Atkinson, J H, McCutchan, J A, StraitsTröster, K., Chandler, J. L., et al. (1995). Stress and depressive symptoms prospectively predict immune change among HIV-seropositive men. HIV Neurobehavioral Research Center Group. Psychiatry, Vol. 58, No. 4, (Nov 1995), pp. ( 299-312), ISSN 0033-2747

Pereda, M., Ayuso-Mateos, J. L., Gómez Del Barrio, A., Echevarria, S., Farinas, M. C., García Palomo, D., González Macias, J., et al. (2000). Factors associated with neuropsychological performance in HIV-seropositive subjects without AIDS. Psychological Medicine, Vol. 30, No. 1, (Jan 2000), pp. (205-217), ISSN 0033-2917

Perkins, D. O., Stern, R. A., Golden, R. N., Murphy, C., Naftolowitz, D., \& Evans, D. L. (1994b). Mood disorders in HIV infection: prevalence and risk factors in a nonepicenter of the AIDS epidemic. The American Journal of Psychiatry, Vol. 151, No. 2, (Jun 1990), pp. (233-236), ISSN 0002-953X

Perry, S. W. (1990). Organic mental disorders caused by HIV: update on early diagnosis and treatment. The American Journal of Psychiatry, Vol. 147, No. 6, pp. (696-710), ISSN 0002-953X 
Perry, S., Belsky-Barr, D., Barr, W. B., \& Jacobsberg, L. (1989). Neuropsychological function in physically asymptomatic, HIV-seropositive men. The Journal of Neuropsychiatry and Clinical Neurosciences, Vol. 1, No. 3, pp. (296-302), ISSN 0895-0172

Pukay-Martin, N. D., Cristiani, S. A., Saveanu, R., \& Bornstein, Robert A. (2003). The relationship between stressful life events and cognitive function in HIV-infected men. The Journal of Neuropsychiatry and Clinical Neurosciences, Vol. 15, No. 4, pp. (436-441), ISSN 0895-0172

Rabkin, J. G., Ferrando, S. J., van Gorp, W., Rieppi, R., McElhiney, M., \& Sewell, M. (2000). Relationships among apathy, depression, and cognitive impairment in HIV/AIDS. The Journal of Neuropsychiatry and Clinical Neurosciences, Vol. 12, No. 4, pp. (451-457), ISSN 0895-0172

Reger, M. A., Martin, D. J., Cole, S. L., \& Strauss, G. (2005). The relationship between plasma viral load and neuropsychological functioning in HIV-1 infection. Archives of Clinical Neuropsychology: The Official Journal of the National Academy of Neuropsychologists, Vol. 20, No. 2, (Mar 2005), pp. (137-143), ISSN 0887-6177

Richardson, M. A., Satz, P. F., Myers, H. F., Miller, E. N., Bing, E. G., Fawzy, F. I., \& Maj, M. (1999j). Effects of depressed mood versus clinical depression on neuropsychological test performance among African American men impacted by HIV/AIDS. Journal of Clinical and Experimental Neuropsychology, Vol. 21, No. 6, (Dec 1999), pp. (769-783), ISSN 1380-3395

Rippeth, J. D., Heaton, Robert K, Carey, C. L., Marcotte, Thomas D, Moore, D. J., Gonzalez, R., Wolfson, Tanya, et al. (2004). Methamphetamine dependence increases risk of neuropsychological impairment in HIV infected persons. Journal of the International Neuropsychological Society: JINS, Vol. 10, No. 1, (Jan 2004), pp. (1-14), ISSN 1355-6177

Ryan, E. L., Baird, R., Mindt, M. R., Byrd, D., Monzones, J., \& Bank, S. M. (2005). Neuropsychological impairment in racial/ethnic minorities with HIV infection and low literacy levels: effects of education and reading level in participant characterization. Journal of the International Neuropsychological Society: JINS, Vol. 11, No. 7, (Nov 2005), pp. (889-898), ISSN 1355-6177

Satz, P., Morgenstern, H., Miller, E. N., Selnes, O. A., McArthur, J. C., Cohen, B. A., Wesch, J., et al. (1993). Low education as a possible risk factor for cognitive abnormalities in HIV-1: findings from the multicenter AIDS Cohort Study (MACS). Journal of Acquired Immune Deficiency Syndromes, Vol. 6, No. 5, (May 1993), pp. (503-511), ISSN 0894-9255

Schmitt, F. A., Bigley, J. W., McKinnis, R., Logue, P. E., Evans, R. W., \& Drucker, J. L. (1988). Neuropsychological outcome of zidovudine (AZT) treatment of patients with AIDS and AIDS-related complex. The New England Journal of Medicine, Vol. 319, No. 24, (Dec 1988), pp. (1573-1578), ISSN 0028-4793

Selnes, O. A., Galai, N., Bacellar, H., Miller, E. N., Becker, J. T., Wesch, J., Van Gorp, W., et al. (1995). Cognitive performance after progression to AIDS: a longitudinal study from the Multicenter AIDS Cohort Study. Neurology, Vol. 45, No. 2, (Feb 1995), pp. (267275), ISSN 0028-3878

Selnes, O. A., McArthur, J. C., Royal, W., 3rd, Updike, M. L., Nance-Sproson, T., Concha, M., Gordon, B., et al. (1992l). HIV-1 infection and intravenous drug use: longitudinal neuropsychological evaluation of asymptomatic subjects. Neurology, Vol. 42, No. 10, (Oct 1992), pp. (1924-1930), ISSN 0028-3878

Selnes, O. A., Miller, E., McArthur, J., Gordon, B., Muñoz, A., Sheridan, K., Fox, R., et al. (1990). HIV-1 infection: no evidence of cognitive decline during the asymptomatic 
stages. The Multicenter AIDS Cohort Study. Neurology, Vol. 40, No. 2, (Feb 1990), pp. (204-208), ISSN 0028-3878.

Sidtis, J. J., Gatsonis, C., Price, R. W., Singer, E. J., Collier, A. C., Richman, D. D., Hirsch, M. S., et al. (1993). Zidovudine treatment of the AIDS dementia complex: results of a placebo-controlled trial. AIDS Clinical Trials Group. Annals of Neurology, Vol. 33, No. 4, (Apr 1993), pp. (343-349), ISSN 0364-5134

Stankoff, B., Calvez, V., Suarez, S., Bossi, P., Rosenblum, O., Conquy, L., Turell, E., et al. (1999). Plasma and cerebrospinal fluid human immunodeficiency virus type-1 (HIV-1) RNA levels in HIV-related cognitive impairment. European Journal of Neurology: The Official Journal of the European Federation of Neurological Societies, Vol. 6, No. 6, (Nov 1999), pp. (669-675), ISSN 1351-5101

Stern, R. A., Silva, S. G., Chaisson, N., \& Evans, D. L. (1996). Influence of cognitive reserve on neuropsychological functioning in asymptomatic human immunodeficiency virus-1 infection. Archives of Neurology, Vol. 53, No. 2, (Feb 1996), pp. (148-153), ISSN 0003-9942

Stern, Y. (1991). The impact of human immunodeficiency virus on cognitive function. Annals of the New York Academy of Sciences, Vol. 640, pp. (219-223), ISSN 0077-8923

Stout, J. C., Ellis, R J, Jernigan, T. L., Archibald, S. L., Abramson, I., Wolfson, T, McCutchan, J A, et al. (1998). Progressive cerebral volume loss in human immunodeficiency virus infection: a longitudinal volumetric magnetic resonance imaging study. HIV Neurobehavioral Research Center Group. Archives of Neurology, Vol. 55, No. 2, (Feb 1998), pp. (161-168), ISSN 0003-9942

Tashima, K. T. (1998). Cerebrospinal fluid levels of antiretroviral medications: abstract and commentary. JAMA: The Journal of the American Medical Association, Vol. 280, No. 10, (Sep 1998), pp. (879-880), ISSN 0098-7484.

van Gorp, W. G., Miller, E. N., Satz, P., \& Visscher, B. (1989). Neuropsychological performance in HIV-1 immunocompromised patients: a preliminary report. Journal of Clinical and Experimental Neuropsychology, Vol. 11, No. 5, (Oct 1989), pp. (763-773), ISSN 1380-3395

Wellman, M. C. (1992). Neuropsychological impairment among intravenous drug users in pre-AIDS stages of HIV infection. The International Journal of Neuroscience, Vol. 64, No. 1-4, (May-Jun 1992), pp. (183-194), ISSN 0020-7454

Zaitseva, M., Peden, K., \& Golding, H. (2003). HIV coreceptors: role of structure, posttranslational modifications, and internalization in viral-cell fusion and as targets for entry inhibitors. Biochimica Et Biophysica Acta, Vol. 1614, No. 1, (Jul 2003), pp. (51-61), ISSN 0006-3002 


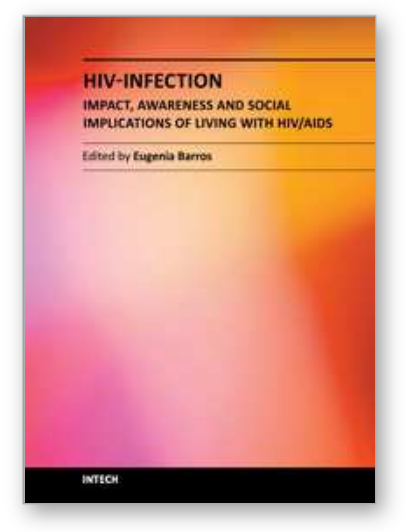

\section{HIV-infection - Impact, Awareness and Social Implications of living with HIV/AIDS}

Edited by Dr. Eugenia Barros

ISBN 978-953-307-343-9

Hard cover, 336 pages

Publisher InTech

Published online 26, October, 2011

Published in print edition October, 2011

The past few decades have seen the escalation of HIV-infections and the 'frantic' search for new drugs to treat the millions of people that live with HIV-AIDS. However because HIV-AIDS cannot be cured, but only controlled with drugs, and the Antiretroviral (ARV) treatment itself results in some undesirable conditions, it is important to generate wider awareness of the plight of people living with this condition. This book attempts to provide information of the initiatives that have been used, successfully or unsuccessfully, to both prevent and combat this 'pandemic' taking into consideration the social, economic, cultural and educational aspects that involve individuals, communities and the countries affected.

\section{How to reference}

In order to correctly reference this scholarly work, feel free to copy and paste the following:

Yogita Rai, Tanusree Dutta and Ambak Kumar Rai (2011). Factors Associated with Neuropsychological Impairment in HIV Infection, HIV-infection - Impact, Awareness and Social Implications of living with HIV/AIDS, Dr. Eugenia Barros (Ed.), ISBN: 978-953-307-343-9, InTech, Available from:

http://www.intechopen.com/books/hiv-infection-impact-awareness-and-social-implications-of-living-with-hivaids/factors-associated-with-neuropsychological-impairment-in-hiv-infection

\section{INTECH}

open science | open minds

\section{InTech Europe}

University Campus STeP Ri

Slavka Krautzeka 83/A

51000 Rijeka, Croatia

Phone: +385 (51) 770447

Fax: +385 (51) 686166

www.intechopen.com

\section{InTech China}

Unit 405, Office Block, Hotel Equatorial Shanghai

No.65, Yan An Road (West), Shanghai, 200040, China

中国上海市延安西路65号上海国际贵都大饭店办公楼 405 单元

Phone: +86-21-62489820

Fax: +86-21-62489821 
(C) 2011 The Author(s). Licensee IntechOpen. This is an open access article distributed under the terms of the Creative Commons Attribution 3.0 License, which permits unrestricted use, distribution, and reproduction in any medium, provided the original work is properly cited. 